States Atomic Energy Commission, 1959), details are given of the proposed regulations approving the form of nuclear energy liability insurance policies and Commission indemnity agreements. Amendments to the indemnity proposals of the Atomic Energy Act, 1954, which it is proposed to submit to Congress, exclude liability for damage to property located at the site of, or used in connexion with, the licensed activity, and would authorize the Commission to fill a gap for a sufficient period of time in which to give the licensee reasonable opportunity to furnish the required protection. The Commission is also studying the possible gaps resulting from the 'common occur. rence' provision, and has entered into a contract for a study of eriticality hazards as part of its continuing study of the problem of extending indemnity to materials licensees. As regards foreign liability problems, the efforts of the Commission have been directed primarily to encouragement and support of the efforts of other governments to enact their own legislation and effect international arrangements.

\section{Scientific Staff in New Zealand}

DURING the past twelve months, six officers of the Ruakura Animal Research Station in New Zealand have rosigned to accept posts in Australia. All have received an increase of salary of $£ A 500$ to $£ A 1,000$ on taking up their new posts. The maxima attached to their new position in Australia is, in all casos, about twice that offered for the positions they vacated in New Zealand. Another 25 individuals have resigned from Governmont laboratories or science departments of New Zealand universities during the past three years to accept overseas posts, mainly in Australia. This figure does not include graduates in science who have gone overseas for advanced training.

Both Government departments and the universities experience great difficulty in replacing the losses of scientific staff with persons of the desired quality. The Soil Bureau of the Department of Scientific and Industrial Research has been seeking pedologists for some time without success, and advertisements for mycologists, entomologists, mathematicians and physiologists have failed to attract any applicants or applicants of the desired qualifications and calibre. Whereas five years ago there were usually a number of highly qualified applicants for each vacancy from which selection could be made, the position has changed so that to-day only one or two such applicants and sometimes none at all apply for advertised positions.

\section{Scientific Research in British Universities}

"SCIEnTIFIC Research in British Universities, 1958-59", based, as in previous years, on material collected by the British Council from heads of departments of the universities, who are alone responsible for the entries, now runs to 446 pages (pp. xii +446. London: H.M. Stationery Office, 1959. 25s. net). These brief notes on scientific research in progress during the 1958-59 session indicate the nature of the projects in sufficient detail to show the scope of the research. Entries are arranged in alphabetical order of university or university college, and under each institution the arrangement is alphabetically by subject. The head of the department is named, with those permanent members of staff actually engaged in supervising research. There are alphabetical name and subject indexes.

\section{Registration of Scientific and Technical Persons, 1958}

Fresh and renewed registrations for all professional classes covered by the Technical and Scientific Register of the Ministry of Labour, with the exception of mathematicians and physicists, steadily increased during 1958, according to the Ministry's annual report. At the end of December, registrations, including those seeking a change as well as those employed, were 29 per cent higher than in December 1957, a significant part of the increase comprising rogistrations of men in the middle age groups seeking better positions before age restricted their prospects and from ex-regular members of the Forces who had retired or anticipated premature retirement. At December 8,1958 , of 4,556 on the register, compared with 3,538 in $1957,1,326$ were unemployed. Premature retirements from the Services reached a peak during the year, but the Regular Forces Resettlement Service, set up by the Ministry, received encouraging support from industry and commerce, and there was no significant increase at the end of the year in the number of such applicants unemployed. The report also directs attention to the establishment in July 1958 by the British Employers' Confederation, the Trades Union Congress and the boards of the nation. alized industries, of the Industrial Training Council in accordance with the recommendation of the Carr Committee. This Council has undertaken as its first task the encouragement of industry generally to take advantage of the opportunities provided by the 'bulge' of school-leavers to expand apprentice. ship sehemes and other forms of training. Thirty-two appointments were made to the general factory inspectorate, and with five applicants awaiting appointment, the number of vacancies at the end of the year was nine. Five additional appointments were made to the Engineoring and Chemical Branches of the inspectorate. On the advice of the National Advisory Committee on the Employment of Older Men and Women, the Ministry is discussing with the Department of Scientific and Industrial Research and the Medical Research Council arrangements to ensure co-operation between the Ministry, industry and research organizations and to stimulate research into problems of employment of older workers.

\section{Rubber Research}

THE twenty-second "Annual Report on the Progress of Rubber 'Technology" covers the progress of rubber technology during the year 1958 (edited by Dr. T. J. Drakeley. Pp. ix $+125+$ xii. Cambridge : W. Heffer and Sons, Ltd., 1959. Published for the Institution of the Rubber Industry). The report contains twenty-three sections, by different contributors, covering all aspects of the technology of rubber-like materials, both natural and synthetic, ranging from surgical goods to the use of rubber in roads. The report also includes sections on historical and economic aspects, planting and production of natural rubber, fibres and fabrics used in conjunction with rubber, compounding ingredients and, for the first time, a separate section on the manufacture of synthetic rubbers. The introduction of this latter section is timely since 1958 saw the opening in Italy, Germany and the United Kingdom of the first major European plants for the production of general-purpose synthetic rubber. Synthetic elastomers are now firmly established as a large and important part of the rubber industry. Already approximately 65 per cent of American new-rubber consumption consists 